\title{
Novel conditioning regimens for bone marrow transplantation
}

This article was published in the following Dove Press journal:

Blood and Lymphatic Cancer:Targets and Therapy

7 January 2013

Number of times this article has been viewed

\author{
Ming Shi \\ Ming Li \\ Susumu Ikehara \\ Department of Stem Cell Disorders, \\ Kansai Medical University, Moriguchi \\ City, Osaka, Japan
}

\begin{abstract}
Bone marrow transplantation (BMT) has evolved into an effective strategy for the treatment of hematological and oncological disorders. Radiotherapy and chemotherapy are used as conditioning regimens prior to BMT to suppress host immunity and reduce tumor burden. High doses of total body irradiation are conventionally administered along with alkylating agents, ie, the myeloablative regimen, to help ensure rapid engraftment of donor cells and to prevent relapse. However, the toxicity of the myeloablative conditioning regimen and unacceptable nonrelapse mortality rules out this approach for older patients by whom less intense preparative regimens are likely to be better tolerated. The reduced-intensity and nonmyeloablative conditioning regimens have been demonstrated by many investigators to be novel approaches resulting in a lower nonrelapse mortality rate and lower incidence of severe acute graft versus host disease. Here, we review the conditioning regimens employed as a pretreatment for BMT, and focus on the novel conditioning regimens and cutting edge developments.
\end{abstract}

Keywords: myeloablative conditioning regimen, reduced-intensity conditioning, nonmyeloablative conditioning regimen, relapse, nonrelapse mortality, graft versus host disease

\section{Introduction}

Bone marrow transplantation (BMT) was originally developed to treat congenital immunodeficiencies and hematologic disorders. ${ }^{1,2}$ BMT has also become a powerful strategy for treating autoimmune and metabolic diseases..$^{3-7}$ Diseases frequently encountered in BMT are listed in Table 1. Radiotherapy and/or chemotherapy are prerequisites for recipients of BMT, because these conditioning regimens are essential for successful transplantation. Because the majority of BMT procedures are performed for the treatment of malignant disease, the conditioning regimens could be used to provide tumor cytoreduction and ideally disease eradication. The therapeutic effects of BMT on malignancies are also mediated via induction of the graft versus tumor effect by immunocompetent cells in the graft. Conditioning regimens that can minimize graft versus host disease without jeopardizing engraftment and graft versus tumor effects are being explored. ${ }^{8}$

The intensity of the conditioning regimens varies significantly. Based on the expected duration and reversibility of cytopenia after BMT, Bacigalupo et al classified the conditioning regimens into three categories, ie, myeloablative, reduced-intensity, and nonmyeloablative conditioning regimens. ${ }^{9}$ Myeloablative conditioning regimens result in irreversible cytopenia, and stem cell support is required after BMT. The highdose radiotherapy and chemotherapy used in the myeloablative conditioning regimens 
Table I Diseases frequently encountered in bone marrow transplantation

\begin{tabular}{ll}
\hline Autologous BMT & Allogeneic BMT \\
\hline Multiple myeloma & Acute myeloid leukemia \\
Non-Hodgkin lymphoma & Acute lymphoblastic leukemia \\
Hodgkin disease & Chronic myeloid leukemia \\
Acute myeloid leukemia & Chronic lymphocytic leukemia \\
Neuroblastoma & Myeloproliferative disorders \\
Germ cell tumors & Myelodysplastic syndromes \\
Autoimmune disorders & Multiple myeloma \\
& Non-Hodgkin lymphoma \\
& Hodgkin disease \\
& Aplastic anemia \\
\hline
\end{tabular}

Note: Multiple myeloma continues to be the most common indication for autotransplantation and acute myeloid leukemia for allogeneic transplantation.

reduce immunocompetent cells in the recipient, permitting rapid engraftment of even unrelated, mismatched donor bone marrow cells. However, the myeloablative conditioning regimens are associated with considerable morbidity and mortality. ${ }^{10}$ Therefore, these approaches have been restricted to young patients without comorbidities, and 50 years is considered an upper age limit.

In contrast with the consensus on a definition of myeloablative conditioning regimens, there are different opinions about reduced-intensity and nonmyeloablative conditioning regimens. Researchers sometimes refer to some of the conventional nonmyeloablative regimens as "reduced-intensity" conditioning regimens. ${ }^{11-13}$ "Reducedintensity conditioning" has also been used instead of "nonmyeloablative" directly. ${ }^{14}$ Even though these regimens have been variably named nonmyeloablative conditioning or reduced-intensity conditioning regimens, they share one important characteristic, ie, both result in reversible myelosuppression (usually within 28 days) when given without stem cell support. ${ }^{12}$ Above all, these methods use lower doses of cytoreductive treatments and result in low nonhematological toxicity. Some researchers use terms such as "intermediate-intensity" conditioning and semi-intensive conditioning rather than reduced-intensity conditioning. ${ }^{15,16}$ Therefore, we have put reduced-intensity and nonmyeloablative conditioning regimens together in this review when discussing those regimens that are not myeloablative and are less toxic. ${ }^{17-19}$

Here, we review the conditioning regimens that are performed as pretreatments for BMT, and focus on some novel conditioning methods (reduced-intensity and nonmyeloablative conditioning regimens) with lower intensity that have expanded the use of BMT to older patients and to those with comorbidities.

\section{Myeloablative conditioning regimens}

Total body irradiation was the first conditioning method developed from research of radiation exposure and has been widely used in the conditioning regimens for its powerful immunosuppressive effects and activity against a variety of malignancies. Early myeloablative total body irradiation regimens were carried out using single large fractions of 8-10 Gy. However, such treatment was not tolerated well and was associated with serious toxicity, which resulted in interstitial pneumonitis, and severe nausea/vomiting..$^{20,21}$ To reduce the side effects of these high doses of total body irradiation while maintaining or improving efficacy, both fractionation and reductions in dose rates were developed. . $2,23^{23}$

Host bone marrow can also be ablated with chemotherapy. Furthermore, chemotherapy can reduce or eradicate the tumor burden, while reducing the long-term sequelae of total body irradiation, including cataracts, sterility, and secondary malignancies. The combination of busulfan and cyclophosphamide is currently the most widely used myeloablative conditioning regimen without incorporating total body irradiation to treat malignant and nonmalignant hematological disorders with allogeneic BMT. ${ }^{24-26}$ Yet, specific metabolites of cyclophosphamide are known to be associated with increased transplantation-induced mortality after conditioning, especially with busulfan. Therefore, fludarabine, a purine analog, has been used in an attempt to replace the cyclophosphamide in the busulfan and cyclophosphamide combination for myeloablative allogeneic BMT as well as nonmyeloablative transplantation. Fludarabine has considerable efficacy in both immunosuppression and tumor cell killing with minimal extramedullary toxicity. The regimen of busulfan and fludarabine has exhibited lower nonrelapse mortality and higher overall survival in patients with low-risk disease than busulfan and cyclophosphamide. ${ }^{25,27}$

Other possible alkylating agents, such as nitrosoureas (eg, carmustine), melphalan, thiotepa, and etoposide, have been included in the conditioning regimens in some trials. For example, the combination of carmustine, etoposide, cytarabine, and melphalan (BEAM) was designed to provide antilymphoma activity without the toxicity of total body irradiation. BEAM has proven to be an effective preparative regimen for its feasibility and tolerability in patients with lymphoma treated by both autologous and allogeneic BMT. ${ }^{28,29}$

Total body irradiation is often combined with chemotherapy in conditioning regimens and appears to provide benefit over conditioning with chemotherapy alone in many settings. ${ }^{30-32}$ The combination of cyclophosphamide and total body irradiation (CyTBI) is considered to be one of the 
standard regimens by many transplant centers. ${ }^{23,26,33,34}$ Some studies have shown the combination of alkylating agents and total body irradiation to have a number of advantages in the conditioning for treatment of high-risk malignancies and solid tumors but with less toxicity. ${ }^{35} \mathrm{CyTBI}$ and busulfan and cyclophosphamide are currently the most commonly used regimens in all BMT clinical practice, including myeloablative, reduced-intensity, and nonmyeloablative conditioning regimens. ${ }^{11,26,34}$ Comparative studies on clinical therapeutic effects of CyTBI and busulfan and cyclophosphamide have indicated that different regimens and types of malignant diseases may affect the outcome. ${ }^{36}$ The myeloablative regimens mentioned above are summarized in Table 2.

\section{Reduced-intensity and nonmyeloablative conditioning regimens}

\section{Pros and cons of reduced-intensity and nonmyeloablative conditioning regimens}

Although dose intensification of myeloablative conditioning regimens had been shown to be effective in reducing the incidence of relapses, it resulted in unacceptable nonrelapse mortality due to regimen-related toxicity. Many studies have endeavored to identify an ideal conditioning regimen that would provide sufficient disease control to allow for sustained remission but without inducing unacceptable levels of toxicity and nonrelapse mortality. Reduced-intensity and nonmyeloablative conditioning regimens have been offered as alternatives to conventional high-dose radiotherapy and

Table 2 Summary of frequently used myeloablative regimens

\begin{tabular}{|c|c|c|c|}
\hline Regimen & $\begin{array}{l}\text { Radiotherapy and } \\
\text { chemotherapy }\end{array}$ & Total dose & Reference \\
\hline BuCy & $\begin{array}{l}\text { Busulfan } \\
\text { Cyclophosphamide }\end{array}$ & $\begin{array}{l}\text { po: } 16 \mathrm{mg} / \mathrm{kg} \text { or } \\
\text { iv: } 12.8-16 \mathrm{mg} / \mathrm{kg} \\
\text { iv: } 120 \mathrm{mg} / \mathrm{kg} \text { or } \\
3.6 \mathrm{~g} / \mathrm{m}^{2}\end{array}$ & $\begin{array}{l}22-26,37 \\
38\end{array}$ \\
\hline BuFlu & $\begin{array}{l}\text { Busulfan } \\
\text { Fludarabine }\end{array}$ & $\begin{array}{l}\text { po: } 16 \mathrm{mg} / \mathrm{kg} \text { or } \\
\text { iv: } 12.8 \mathrm{mg} / \mathrm{kg} \\
\text { iv: } 180-200 \mathrm{mg} / \mathrm{m}^{2}\end{array}$ & 25,27 \\
\hline СутВІ & $\begin{array}{l}\text { Cyclophosphamide } \\
\text { TBI }\end{array}$ & $\begin{array}{l}\text { iv: } 120 \mathrm{mg} / \mathrm{kg} \text { or } \\
3.6 \mathrm{~g} / \mathrm{m}^{2} \\
8-15.75 \mathrm{~Gy}\end{array}$ & $\begin{array}{l}23,26,33 \\
34,38\end{array}$ \\
\hline BEAM & $\begin{array}{l}\text { Carmustine } \\
\text { Etoposide } \\
\text { Cytarabine } \\
\text { Melphalan }\end{array}$ & $\begin{array}{l}\text { iv: } 300 \mathrm{mg} / \mathrm{m}^{2} \\
\text { iv: } 400-800 \mathrm{mg} / \mathrm{m}^{2} \\
\text { iv: } 800-1600 \mathrm{mg} / \mathrm{m}^{2} \\
\text { iv: } 140 \mathrm{mg} / \mathrm{m}^{2}\end{array}$ & 28,29 \\
\hline СуATG & $\begin{array}{l}\text { Cyclophosphamide } \\
\text { ATG }\end{array}$ & $\begin{array}{l}\text { iv: } 200 \mathrm{mg} / \mathrm{kg} \\
\text { iv: } 90 \mathrm{mg} / \mathrm{kg}\end{array}$ & 63 \\
\hline
\end{tabular}

Abbreviations: po, per os; iv, intravenous; TBI, total body irradiation; ATG, antithymocyte globulin. chemotherapy for older patients undergoing BMT on the basis that the less intense preparative regimens are likely to produce considerably less organ toxicity, so would be better tolerated by such patients. One report compares the outcome of myeloablative and nonmyeloablative conditioning regimens in patients older than 50 years, and suggests that the nonmyeloablative conditioning regimen led to improved overall survival at one year and 2 years. A significantly lower nonrelapse mortality rate was observed in the nonmyeloablative conditioning regimen group than in the myeloablative conditioning group (32\% versus 50\%). ${ }^{37}$ For patients who were heavily pretreated and already refractory to therapy, such as in indolent lymphoma, the majority demonstrated donor engraftment and there was a high rate of complete remission. ${ }^{13}$ One third of patients who underwent nonmyeloablative conditioning had failed prior high-dose myeloablative conditioning BMT. ${ }^{38}$ Therefore, reducedintensity and nonmyeloablative conditioning regimens have been used with increasing frequency, particularly in older patients with hematological malignancies and in patients considered at high risk for treatment-related toxicity and mortality associated with high-dose myeloablative conditioning regimens. ${ }^{39,40}$

Secondly, reduced-intensity and nonmyeloablative conditioning regimens may reduce the risk of severe acute graft versus host disease. These regimens cause only limited host damage, which may subsequently translate into less release of inflammatory cytokines which, it has been proposed, provide a proinflammatory milieu for development of graft versus host disease. ${ }^{41}$ In addition, development of transient mixed donor-host chimerism after reduced-intensity and nonmyeloablative conditioning regimens may facilitate the establishment of mutual tolerance, which in turn downregulates the activity of graft versus host disease. ${ }^{42}$ Residual host $T$ cells also play a role in the suppression of graft versus host disease. Results from the Fred Hutchinson Cancer Research Center showed that the incidence of severe acute graft versus host disease was significantly lower in nonmyeloablative conditioning patients (grades III-IV acute graft versus host disease, $17 \%$ in the nonmyeloablative conditioning group versus $35 \%$ in the myeloablative conditioning group). ${ }^{38}$ There is some controversy regarding the incidence of severe acute graft versus host disease in patients given reduced-intensity and nonmyeloablative conditioning regimens. ${ }^{37}$ The timing of onset of acute graft versus host disease after reducedintensity and nonmyeloablative conditioning regimens is delayed, and may develop after day 100, at a time when chronic graft versus host disease is usually diagnosed after 
the myeloablative conditioning regimens. ${ }^{42}$ More recently developed nonmyeloablative conditioning regimens have shifted some or all of the burden of killing tumor cells from the conditioning regimen to the graft versus tumor effects. ${ }^{43}$ Therefore, donor lymphocyte infusion, which has been used as a helpful tool for inducing a sustained complete response of malignancies but which is always followed by serious graft versus host disease in myeloablative conditioning regimens, could replace high-dose cytotoxic therapy because of its graft versus tumor effects in reduced-intensity and nonmyeloablative conditioning regimens. ${ }^{44}$ Donor lymphocyte infusion performed after these conditioning regimens has shown promising results, even in the treatment of solid malignancies in both animal and clinical studies. ${ }^{17,45}$

Thirdly, the defense provided by the host's immune system is partly protected because the reduced-intensity and nonmyeloablative conditioning regimens do not immediately and completely eliminate host-derived immunocompetent cells, and the level of host neutropenia is reduced. This is extremely important for early immunity after transplantation, and infectious complications may be reduced. ${ }^{46}$

Recent advances with reduced-intensity and nonmyeloablative conditioning regimens have significantly decreased early mortality and acute graft versus host disease, while enabling robust and prompt engraftment, and hence enhancing the therapeutic benefits of BMT. ${ }^{47}$ However, there are also potential disadvantages of using these condition regimens, disease relapse being a primary cause of treatment failure for patients receiving them. In one study, a higher rate of relapse (albeit not statistically significant) was observed in patients with myelodysplastic syndrome or acute myeloid leukemia in a nonmyeloablative conditioning group than in the myeloablative conditioning group ( $46 \%$ versus $30 \%$, $P=0.052) .{ }^{37}$ Similar results have been reported by other groups, and greater intensity leads to less relapse, although possibly at the expense of higher nonrelapse mortality. ${ }^{48,49}$ Chronic graft versus host disease is another disadvantage of reduced-intensity and nonmyeloablative conditioning regimens. The incidence and times of onset of chronic extensive graft versus host disease were similar between myeloablative and reduced-intensity and nonmyeloablative conditioning regimens. ${ }^{38}$

Candidate patients for reduced-intensity and nonmyeloablative conditioning regimens often have adverse characteristics, including advancing age, higher risk diseases, and higher pretransplantation comorbidity scores. However, despite the potential disadvantages, considering these unfavorable factors and the improvements in nonrelapse mortality, acute graft versus host disease suppression, progression-free survival, and overall survival, the overall outcome of these conditioning regimens is encouraging, and the number of BMT operations performed using them for a variety of hematological conditions is increasing dramatically. ${ }^{11,37}$

\section{Examples of reduced-intensity and nonmyeloablative conditioning regimens}

Low-dose (2-3 Gy) total body irradiation alone is an easy and convenient nonmyeloablative conditioning regimen. Its intensity is, to the best of our knowledge, the lowest in use today. Fludarabine is added in low doses in an attempt to reduce the risk of graft rejection. Low-dose total body irradiation, with or without fludarabine $90 \mathrm{mg} / \mathrm{m}^{2}$, is a minimally toxic regimen developed for allogeneic BMT to treat patients with advanced hematological malignancies who are older or have comorbid conditions. It is one of the most widely used regimens by clinical centers. ${ }^{11,38,42-44,50,51}$ Prospective clinical allogeneic BMT trials have shown that, in patients aged 60-75 years treated with this regimen, 5-year overall and 5 -year progression-free survival rates were $35 \%$ and $32 \%$, respectively. ${ }^{52}$

Other chemotherapy drugs, especially alkylating agents, are often combined with fludarabine. FAI is a regimen consisting of fludarabine, cytarabine, and idarubicin, and busulfan and fludarabine is a regimen used in myeloablative conditioning, but at much lower doses..$^{37,49}$

The intensity of regimens increases with the doses of chemotherapy. Similar doses of fludarabine plus intermediate doses of one or two alkylating agents or low dose total body irradiation would be more powerful in host cytoreduction. Lim et al defined the intermediate doses of alkylating agents as oral busulfan $(8-10 \mathrm{mg} / \mathrm{kg})$, intravenous melphalan $\left(80-140 \mathrm{mg} / \mathrm{m}^{2}\right)$, intravenous cyclophosphamide $\left(600-1200 \mathrm{mg} / \mathrm{m}^{2}\right)$, or intravenous thiotepa $(5-10 \mathrm{mg} / \mathrm{kg}){ }^{48}$ The doses employed by different clinical centers may be quite different. For example, the combination of fludarabine and melphalan varies from fludarabine $100-150 \mathrm{mg} / \mathrm{m}^{2}$ and melphalan $140-180 \mathrm{mg} / \mathrm{m}^{2}$ to fludarabine $90-120 \mathrm{mg} / \mathrm{m}^{2}$ and melphalan $90-140 \mathrm{mg} / \mathrm{m}^{2} .49,53,54 \mathrm{In}$ the regimen consisting of fludarabine and cyclophosphamide, the dose of cyclophosphamide in the research of Anderlini et al is 2.5-3 times the dose used by Lim et al. ${ }^{48,54}$

New drugs have been developed and added to the conditioning regimens. Treosulfan has been used as a substitute for busulfan in frail patients, because the side effects and toxicity are supposedly less severe. Treosulfan-based conditioning regimens have shown a favorable safety profile with fast 
and sustained engraftment. ${ }^{18,19,55}$ Recently, Nemecek et al have reported that a conditioning regimen consisting of treosulfan and fludarabine is well tolerated and yields encouraging survival rates and disease control with minimal nonrelapse mortality in patients with high-risk hematological malignancies. ${ }^{39}$ Clofarabine is a second-generation purine nucleoside analog that combines the properties of fludarabine and cladribine. It is one of the most effective single agents against leukemic blast. ${ }^{56}$ The combination of clofarabine with the reduced-intensity conditioning regimen showed good antileukemic efficacy, even in patients with high-risk acute myeloid leukemia or myelodysplastic syndrome. ${ }^{57}$ Tyrosine kinase inhibitors can lead to cytogenetic remissions in patients with chronic myeloid leukemia and have been used before reduced-intensity or nonmyeloablative conditioning regimens. Warlick et al reported that allogeneic reduced-intensity conditioning BMT for older patients with chronic myeloid leukemia can control relapse with acceptable toxicity. ${ }^{58}$

\section{Novel reduced-intensity and nonmyeloablative conditioning regimens Total lymphoid irradiation}

Efforts have been made clinically to reduce toxicity through using total lymphoid irradiation rather than total body irradiation to protect critical organs. Total lymphoid irradiation was initially used with the combination of conventional myeloablative regimens to increase immunosuppression and engraftment further. ${ }^{59}$ Research in animals showed that total lymphoid irradiation increased the proportion of regulatory natural killer $\mathrm{T}$ cells. These natural killer $\mathrm{T}$ cells prevented acute graft versus host disease by inhibiting the proliferation and cytokine secretion of conventional $\mathrm{T}$ cells without affecting graft versus tumor activity ${ }^{60,61}$ Lowsky et al took advantage of the immune system's regulatory natural killer $\mathrm{T}$ cells and evaluated the total lymphoid irradiationbased reduced-intensity conditioning regimen in patients with lymphoid malignancies or acute leukemia undergoing allogeneic BMT. Eight Gy total lymphoid irradiation was delivered with fractions using fields to encompass the thymus, spleen, and lymph nodes. The results showed that $95 \%$ of patients scored as grade 0 according to standard scores for graft versus host disease, and the incidence of severe acute graft versus host disease was only $3 \%$. The reduced-intensity conditioning regimen containing total lymphoid irradiation did not adversely affect the graft versus tumor effects of the allogeneic graft. ${ }^{62}$

\section{Monoclonal antibodies}

In 1994, Storb et al reported a conditioning regimen for patients with aplastic anemia using a high-dose combination of cyclophosphamide and monoclonal antibody to CD3 (antithymocyte globulin). ${ }^{63}$ Subsequently, reduced-intensity conditioning regimens that consisted of antithymocyte globulin and alkylating agents were applied to both nonmalignant and malignant hematological disorders. ${ }^{15,64}$ Promising outcomes were confirmed after regimens that contained antithymocyte globulin by the low incidence of acute graft versus host disease, although chronic graft versus host disease remained a major problem. ${ }^{65,66}$ Therefore the use of other antibodies was explored, a representative being alemtuzumab (monoclonal antibody to CD52, marketed as Campath ${ }^{\circledR}$, Genzyme Corporation, Cambridge, MA). Alemtuzumab has since been proven to be effective and safe in the reducedintensity conditioning regimens by several goups. ${ }^{67-69}$ Recently, a minimal-intensity conditioning regimen using alemtuzumab with fludarabine and cyclophosphamide has been developed by Marsh et al. ${ }^{70}$ The results show that the regimen consisting of fludarabine, cyclophosphamide and alemtuzumab was associated with not only durable engraftment but also a much lower risk of chronic graft versus host disease compared with the conventional regimen containing antithymocyte globulin. ${ }^{70}$ A retrospective study concluded that reduced-intensity conditioning consisting of fludarabine, melphalan, and alemtuzumab significantly improved survival rates over a myeloablative conditioning regimen consisting of busulfan, cyclophosphamide, and antithymocyte globulin plus or minus etoposide. ${ }^{71}$ The anti-CD20 monoclonal antibody, rituximab, has also been used in both myeloablative and reduced-intensity conditioning regimens. ${ }^{72}$ For patients with lymphoma who experienced disease recurrence following autologous BMT, allogeneic BMT prepared with a nonmyeloablative conditioning regimen consisting of fludarabine, cyclophosphamide and rituximab was suggested to be an effective option. ${ }^{73}$

\section{Radioimmunotherapy usage}

Antibodies conjugated with radionuclides, known as radioimmunotherapy, have been used for the treatment of cancer both in animal experiments and clinically. ${ }^{74,75}$ By way of radioimmunotherapy, radiotherapy could be directly delivered to the surface of the targeted cells in continuous low-dose rate irradiation without increasing the toxicity, thereby sparing normal tissue. Therefore, radioimmunotherapy has been used in conditioning regimens to reduce the tumor burden while allowing for long-term disease control through graft versus 
tumor effects in both myeloablative and reduced-intensity conditioning regimens. ${ }^{76}$ Clinically, the radiolabeled anti-CD20 antibody (yttrium-90 ibritumomab tiuxetan) had been administered prior to reduced-intensity conditioning regimens for patients with advanced lymphoma and refractory disease or relapse after a previous autologous BMT. The treatment is associated with favorable outcomes, including no additional toxicity, enhanced cytoreduction, acceptable graft versus host disease, and absence of relapse. ${ }^{77,78}$ Pagel et al have combined iodine-131 labeled anti-CD45 antibody with a standard reduced-intensity conditioning regimen for the treatment of older high-risk patients with acute myeloid leukemia or myelodysplastic syndrome. The results showed that CD45-targeted radiotherapy could be safely combined with a

Table 3 Summary of frequently used reduced-intensity and nonmyeloablative conditioning regimens

\begin{tabular}{|c|c|c|c|}
\hline Regimen & $\begin{array}{l}\text { Radiotherapy and } \\
\text { chemotherapy }\end{array}$ & Total dose & Reference \\
\hline TBI & TBI & 2-3 Gy & $\begin{array}{l}\mid 1,42-44, \\
5 \mid\end{array}$ \\
\hline FluTBI & $\begin{array}{l}\text { Fludarabine } \\
\text { TBI }\end{array}$ & $\begin{array}{l}\text { iv: } 90 \mathrm{mg} / \mathrm{m}^{2} \\
2-3 \mathrm{~Gy}\end{array}$ & $\begin{array}{l}11,38, \\
42-44,50, \\
51\end{array}$ \\
\hline FAI & $\begin{array}{l}\text { Fludarabine } \\
\text { Cytarabine } \\
\text { Idarubicin }\end{array}$ & $\begin{array}{l}\text { iv: } 120 \mathrm{mg} / \mathrm{m}^{2} \\
\text { iv: } 4 \mathrm{~g} / \mathrm{m}^{2} \\
\text { iv: } 36 \mathrm{mg} / \mathrm{m}^{2}\end{array}$ & 49 \\
\hline BuFlu & $\begin{array}{l}\text { Busulfan } \\
\text { Fludarabine }\end{array}$ & $\begin{array}{l}\text { iv: } 3.2 \mathrm{mg} / \mathrm{kg} \\
\text { iv: } 120 \mathrm{mg} / \mathrm{m}^{2}\end{array}$ & 37 \\
\hline FluCy & $\begin{array}{l}\text { Fludarabine } \\
\text { Cyclophosphamide }\end{array}$ & $\begin{array}{l}\text { iv: } 125 \mathrm{mg} / \mathrm{m}^{2} \\
\text { iv: } 3 \mathrm{~g} / \mathrm{m}^{2}\end{array}$ & 54 \\
\hline FluCyATG & $\begin{array}{l}\text { Fludarabine } \\
\text { Cyclophosphamide } \\
\text { ATG }\end{array}$ & $\begin{array}{l}\text { iv: } 125 \mathrm{mg} / \mathrm{m}^{2} \\
\text { iv: } 3 \mathrm{~g} / \mathrm{m}^{2} \\
\text { iv: } 60 \mathrm{mg} / \mathrm{kg}\end{array}$ & 54 \\
\hline FluMel & $\begin{array}{l}\text { Fludarabine } \\
\text { Melphalan }\end{array}$ & $\begin{array}{l}\text { iv: } 90-150 \mathrm{mg} / \mathrm{m}^{2} \\
\text { iv: } 90-180 \mathrm{mg} / \mathrm{m}^{2}\end{array}$ & $49,53,54$ \\
\hline TreoFlu & $\begin{array}{l}\text { Treosulfan } \\
\text { Fludarabine }\end{array}$ & $\begin{array}{l}\text { iv: } 30-42 \mathrm{~g} / \mathrm{m}^{2} \\
\text { iv: } 150 \mathrm{mg} / \mathrm{m}^{2}\end{array}$ & 39 \\
\hline TLIATG & $\begin{array}{l}\text { TLI } \\
\text { ATG }\end{array}$ & $\begin{array}{l}8 \mathrm{~Gy} \\
\text { iv: } 7.5 \mathrm{mg} / \mathrm{kg}\end{array}$ & 62 \\
\hline TreoFluATG & $\begin{array}{l}\text { Treosulfan } \\
\text { Fludarabine } \\
\text { ATG }\end{array}$ & $\begin{array}{l}\text { iv: } 30-42 \mathrm{~g} / \mathrm{m}^{2} \\
\text { iv: } 150 \mathrm{mg} / \mathrm{m}^{2} \\
\text { iv: } 30-90 \mathrm{mg} / \mathrm{m}^{2}\end{array}$ & 18,39 \\
\hline BuFluATG & $\begin{array}{l}\text { Busulfan } \\
\text { Fludarabine } \\
\text { ATG }\end{array}$ & $\begin{array}{l}\text { iv: } 12.8 \mathrm{mg} / \mathrm{kg} \\
\text { iv: } 250 \mathrm{mg} / \mathrm{m}^{2} \\
\text { iv: } 4.5 \mathrm{mg} / \mathrm{kg}\end{array}$ & 66 \\
\hline FCC & $\begin{array}{l}\text { Fludarabine } \\
\text { Cyclophosphamide } \\
\text { Alemtuzumab }\end{array}$ & $\begin{array}{l}\text { iv: } 120 \mathrm{mg} / \mathrm{m}^{2} \\
\text { iv: } 1200 \mathrm{mg} / \mathrm{m}^{2} \\
\text { iv or sc: } \\
40-100 \mathrm{mg}\end{array}$ & 70 \\
\hline FluCyRit & $\begin{array}{l}\text { Fludarabine } \\
\text { Cyclophosphamide } \\
\text { Rituximab }\end{array}$ & $\begin{array}{l}\text { iv: } 90 \mathrm{mg} / \mathrm{m}^{2} \\
\text { iv: } 2250 \mathrm{mg} / \mathrm{m}^{2} \\
\text { iv: } 1375 \mathrm{mg}\end{array}$ & 73 \\
\hline
\end{tabular}

Abbreviations: TBI, total body irradiation; iv, intravenous; TLI, total lymphoid irradiation; ATG, antithymocyte globulin; sc, subcutaneous. reduced-intensity conditioning regimen to yield encouraging overall survival. ${ }^{79}$ The frequently used reduced-intensity and nonmyeloablative conditioning regimens are summarized in Table 3.

\section{Conclusion}

BMT remains a potentially dangerous procedure due to the many possible complications. The myeloablative conditioning regimens depending on high doses of radiotherapy and chemotherapy induce intense toxicity and have a high nonrelapse mortality rate; therefore, the conventional myeloablative conditioning regimens have been modified with the goal of reducing toxicity while maintaining or improving efficacy. Reduced-intensity and nonmyeloablative conditioning regimens have proven to be less toxic, making them suitable for older patients and those with comorbidities. These novel regimens are also associated with a lower rate of nonrelapse mortality and incidence of severe acute graft versus host disease. Host immunity is not completely destroyed in reduced-intensity and nonmyeloablative conditioning regimens and provides partial protection from infections. Reduced-intensity and nonmyeloablative conditioning regimens are appealing alternatives to myeloablative conditioning regimens and make BMT more acceptable by directly or indirectly ameliorating the complications. Efforts to improve effects and outcomes further continue to be explored by researchers, with potentially promising results. ${ }^{80}$

\section{Acknowledgments}

We would like to thank Hilary Eastwick-Field and Keiko Ando for their help in the preparation of the manuscript. This study was supported by Otsuka Pharmaceutical Company Ltd and The Research on Allergic Disease and Immunology Committee from Health and Labour Sciences Research Grants of the Ministry of Health, Labour, and Welfare.

\section{Disclosure}

The authors declare no competing financial interests in this work.

\section{References}

1. Gatti RA, Meuwissen HJ, Allen HD, Hong R, Good RA. Immunological reconstitution of sex-linked lymphopenic immunological deficiency. Lancet. 1968;2(7583):1366-1369.

2. Bach FH, Albertini RJ, Joo P, Anderson JL, Bortin MM. Bone-marrow transplantation in a patient with the Wiskott-Aldrich syndrome. Lancet. 1968;2(7583):1364-1366.

3. Ikehara S. A novel method of bone marrow transplantation (BMT) for intractable autoimmune diseases. J Autoimmun. 2008;30(3):108-115. 
4. Saba N, Flaig T. Bone marrow transplantation for nonmalignant diseases. J Hematother Stem Cell Res. 2002;11(2):377-387.

5. Copelan EA. Hematopoietic stem-cell transplantation. $N$ Engl J Med. 2006;354(17):1813-1826.

6. Gratwohl A, Baldomero H, Aljurf M, et al. Hematopoietic stem cell transplantation: a global perspective. JAMA. 2010;303(16):1617-1624.

7. Passweg JR, Baldomero H, Gratwohl A, et al. The EBMT activity survey: 1990-2010. Bone Marrow Transplant. 2012;47(7):906-923.

8. Welniak LA, Blazar BR, Murphy WJ. Immunobiology of allogeneic hematopoietic stem cell transplantation. Annu Rev Immunol. 2007;25: 139-170.

9. Bacigalupo A, Ballen K, Rizzo D, et al. Defining the intensity of conditioning regimens: working definitions. Biol Blood Marrow Transplant. 2009;15(12):1628-1633.

10. Bearman SI, Appelbaum FR, Buckner CD, et al. Regimen-related toxicity in patients undergoing bone marrow transplantation. $J$ Clin Oncol. 1988;6(10):1562-1568.

11. Gooley TA, Chien JW, Pergam SA, et al. Reduced mortality after allogeneic hematopoietic-cell transplantation. NEngl J Med. 2010;363(22): 2091-2101.

12. Giralt S, Ballen K, Rizzo D, et al. Reduced-intensity conditioning regimen workshop: defining the dose spectrum. Report of a workshop convened by the Center for International Blood and Marrow Transplant Research. Biol Blood Marrow Transplant. 2009;15(3):367-369.

13. Gribben JG, Hosing C, Maloney DG. Stem cell transplantation for indolent lymphoma and chronic lymphocytic leukemia. Biol Blood Marrow Transplant. 2011;17(Suppl 1):S63-S70.

14. Deeg HJ, Maris MB, Scott BL, Warren EH. Optimization of allogeneic transplant conditioning: not the time for dogma. Leukemia. 2006;20(10) 1701-1705.

15. Chemnitz JM, von Lilienfeld-Toal M, Holtick U, et al. Intermediate intensity conditioning regimen containing FLAMSA, treosulfan, cyclophosphamide, and ATG for allogeneic stem cell transplantation in elderly patients with relapsed or high-risk acute myeloid leukemia Ann Hematol. 2012;91(1):47-55.

16. van de Donk NW, Lokhorst HM, Anderson KC, Richardson PG. How I treat plasma cell leukemia. Blood. 2012;120(12):2376-2389.

17. Kami M, Makimoto A, Heike Y, Takaue Y. Reduced-intensity hematopoietic stem cell transplantation (RIST) for solid malignancies Jpn J Clin Oncol. 2004;34(12):707-716.

18. Ruutu T, Volin L, Beelen DW, et al. Reduced-toxicity conditioning with treosulfan and fludarabine in allogeneic hematopoietic stem cell transplantation for myelodysplastic syndromes: final results of an international prospective phase II trial. Haematologica. 2011;96(9): 1344-1350.

19. Kroger N, Shimoni A, Zabelina T, et al. Reduced-toxicity conditioning with treosulfan, fludarabine and ATG as preparative regimen for allogeneic stem cell transplantation (alloSCT) in elderly patients with secondary acute myeloid leukemia (sAML) or myelodysplastic syndrome (MDS). Bone Marrow Transplant. 2006;37(4):339-344.

20. Pino y Torres JL, Bross DS, Lam WC, Wharam MD, Santos GW, Order SE. Risk factors in interstitial pneumonitis following allogenic bone marrow transplantation. Int J Radiat Oncol Biol Phys. 1982;8(8): 1301-1307.

21. Hill-Kayser CE, Plastaras JP, Tochner Z, Glatstein E. TBI during BM and SCT: review of the past, discussion of the present and consideration of future directions. Bone Marrow Transplant. 2011;46(4):475-484.

22. Shank B, Chu FC, Dinsmore R, et al. Hyperfractionated total body irradiation for bone marrow transplantation. Results in seventy leukemia patients with allogeneic transplants. Int J Radiat Oncol Biol Phys. 1983 9(11):1607-1611.

23. Girinsky T, Benhamou E, Bourhis JH, et al. Prospective randomized comparison of single-dose versus hyperfractionated total-body irradiation in patients with hematologic malignancies. $J$ Clin Oncol. 2000;18(5):981-986.

24. Deeg HJ, Storer B, Slattery JT, et al. Conditioning with targeted busulfan and cyclophosphamide for hemopoietic stem cell transplantation from related and unrelated donors in patients with myelodysplastic syndrome. Blood. 2002;100(4):1201-1207.
25. Chae YS, Sohn SK, Kim JG, et al. New myeloablative conditioning regimen with fludarabine and busulfan for allogeneic stem cell transplantation: comparison with BuCy2. Bone Marrow Transplant. 2007;40(6):541-547.

26. Martino R, Iacobelli S, Brand R, et al. Retrospective comparison of reduced-intensity conditioning and conventional high-dose conditioning for allogeneic hematopoietic stem cell transplantation using HLAidentical sibling donors in myelodysplastic syndromes. Blood. 2006; 108(3):836-846.

27. Iravani M, Evazi MR, Mousavi SA, et al. Fludarabine and busulfan as a myeloablative conditioning regimen for allogeneic stem cell transplantation in high- and standard-risk leukemic patients. Bone Marrow Transplant. 2007;40(2):105-110.

28. Mills W, Chopra R, McMillan A, Pearce R, Linch DC, Goldstone AH. BEAM chemotherapy and autologous bone marrow transplantation for patients with relapsed or refractory non-Hodgkin's lymphoma. J Clin Oncol. 1995;13(3):588-595.

29. Przepiorka D, van Besien K, Khouri I, et al. Carmustine, etoposide, cytarabine and melphalan as a preparative regimen for allogeneic transplantation for high-risk malignant lymphoma. Ann Oncol. 1999;10(5): 527-532.

30. Pagel JM, Matthews DC, Appelbaum FR, Bernstein ID, Press OW. The use of radioimmunoconjugates in stem cell transplantation. Bone Marrow Transplant. 2002;29(10):807-816.

31. Kroger N, Zabelina T, Kruger W, et al. Comparison of total body irradiation vs busulfan in combination with cyclophosphamide as conditioning for unrelated stem cell transplantation in CML patients. Bone Marrow Transplant. 2001;27(4):349-354.

32. Davies SM, Ramsay NK, Klein JP, et al. Comparison of preparative regimens in transplants for children with acute lymphoblastic leukemia. J Clin Oncol. 2000;18(2):340-347.

33. Clift RA, Buckner CD, Appelbaum FR, et al. Allogeneic marrow transplantation in patients with acute myeloid leukemia in first remission: a randomized trial of two irradiation regimens. Blood. 1990;76(9): $1867-1871$

34. Toze CL, Galal A, Barnett MJ, et al. Myeloablative allografting for chronic lymphocytic leukemia: evidence for a potent graft-versus-leukemia effect associated with graft-versus-host disease. Bone Marrow Transplant. 2005;36(9):825-830.

35. Moreau P, Facon T, Attal M, et al. Comparison of $200 \mathrm{mg} / \mathrm{m}(2) \mathrm{mel}-$ phalan and 8 Gy total body irradiation plus $140 \mathrm{mg} / \mathrm{m}(2)$ melphalan as conditioning regimens for peripheral blood stem cell transplantation in patients with newly diagnosed multiple myeloma: final analysis of the Intergroupe Francophone du Myelome 9502 randomized trial. Blood. 2002;99(3):731-735.

36. Shi-Xia X, Xian-Hua T, Hai-Qin X, Bo F, Xiang-Feng T. Total body irradiation plus cyclophosphamide versus busulphan with cyclophosphamide as conditioning regimen for patients with leukemia undergoing allogeneic stem cell transplantation: a meta-analysis. Leuk Lymphoma. 2010;51(1):50-60.

37. Alyea EP, Kim HT, Ho V, et al. Comparative outcome of nonmyeloablative and myeloablative allogeneic hematopoietic cell transplantation for patients older than 50 years of age. Blood. 2005;105(4): $1810-1814$

38. Sorror ML, Maris MB, Storer B, et al. Comparing morbidity and mortality of HLA-matched unrelated donor hematopoietic cell transplantation after nonmyeloablative and myeloablative conditioning: influence of pretransplantation comorbidities. Blood. 2004;104(4):961-968.

39. Nemecek ER, Guthrie KA, Sorror ML, et al. Conditioning with treosulfan and fludarabine followed by allogeneic hematopoietic cell transplantation for high-risk hematologic malignancies. Biol Blood Marrow Transplant. 2011;17(3):341-350.

40. Mielcarek M, Sandmaier BM, Maloney DG, et al. Nonmyeloablative hematopoietic cell transplantation: status quo and future perspectives. J Clin Immunol. 2002;22(2):70-74.

41. Ferrara JL, Levine JE, Reddy P, Holler E. Graft-versus-host disease. Lancet. 2009;373(9674):1550-1561. 
42. Mielcarek M, Martin PJ, Leisenring W, et al. Graft-versus-host disease after nonmyeloablative versus conventional hematopoietic stem cell transplantation. Blood. 2003;102(2):756-762.

43. Baron F, Maris MB, Sandmaier BM, et al. Graft-versus-tumor effects after allogeneic hematopoietic cell transplantation with nonmyeloablative conditioning. J Clin Oncol. 2005;23(9):1993-2003.

44. McSweeney PA, Niederwieser D, Shizuru JA, et al. Hematopoietic cell transplantation in older patients with hematologic malignancies: replacing high-dose cytotoxic therapy with graft-versus-tumor effects. Blood. 2001;97(11):3390-3400.

45. Suzuki Y, Adachi Y, Minamino K, et al. A new strategy for treatment of malignant tumor: intra-bone marrow-bone marrow transplantation plus CD4-donor lymphocyte infusion. Stem Cells. 2005;23(3): 365-370.

46. Champlin R, Khouri I, Anderlini P, et al. Nonmyeloablative preparative regimens for allogeneic hematopoietic transplantation. Bone Marrow Transplant. 2001;27 Supp1 2:S13-S22.

47. Koh LP, Chao NJ. Nonmyeloablative allogeneic hematopoietic stem cell transplant using mismatched/haploidentical donors: a review. Blood Cells Mol Dis. 2008;40(1):20-24.

48. Lim Z, Brand R, Martino R, et al. Allogeneic hematopoietic stem-cell transplantation for patients 50 years or older with myelodysplastic syndromes or secondary acute myeloid leukemia. J Clin Oncol. 2010;28(3): 405-411.

49. de Lima M, Anagnostopoulos A, Munsell M, et al. Nonablative versus reduced-intensity conditioning regimens in the treatment of acute myeloid leukemia and high-risk myelodysplastic syndrome: dose is relevant for long-term disease control after allogeneic hematopoietic stem cell transplantation. Blood. 2004;104(3):865-872.

50. Burroughs LM, Torgerson TR, Storb R, et al. Stable hematopoietic cell engraftment after low-intensity nonmyeloablative conditioning in patients with immune dysregulation, polyendocrinopathy, enteropathy, X-linked syndrome. J Allergy Clin Immunol. 2010;126(5):1000-1005.

51. Sorror ML, Maris MB, Storb R, et al. Hematopoietic cell transplantation (HCT)-specific comorbidity index: a new tool for risk assessment before allogeneic HCT. Blood. 2005;106(8):2912-2919.

52. Sorror ML, Sandmaier BM, Storer BE, et al. Long-term outcomes among older patients following nonmyeloablative conditioning and allogeneic hematopoietic cell transplantation for advanced hematologic malignancies. JAMA. 2011;306(17):1874-1883.

53. Efebera YA, Qureshi SR, Cole SM, et al. Reduced-intensity allogeneic hematopoietic stem cell transplantation for relapsed multiple myeloma. Biol Blood Marrow Transplant. 2010;16(8):1122-1129.

54. Anderlini P, Saliba R, Acholonu S, et al. Reduced-intensity allogeneic stem cell transplantation in relapsed and refractory Hodgkin's disease: low transplant-related mortality and impact of intensity of conditioning regimen. Bone Marrow Transplant. 2005;35(10):943-951.

55. Danylesko I, Shimoni A, Nagler A. Treosulfan-based conditioning before hematopoietic SCT: more than a BU look-alike. Bone Marrow Transplant. 2012;47(1):5-14.

56. Jeha S, Razzouk B, Rytting M, et al. Phase II study of clofarabine in pediatric patients with refractory or relapsed acute myeloid leukemia. J Clin Oncol. 2009;27(26):4392-4397.

57. Buchholz S, Dammann E, Stadler M, et al. Cytoreductive treatment with clofarabine/ara-C combined with reduced-intensity conditioning and allogeneic stem cell transplantation in patients with high-risk, relapsed, or refractory acute myeloid leukemia and advanced myelodysplastic syndrome. Eur J Haematol. 2012;88(1):52-60.

58. Warlick E, Ahn KW, Pedersen TL, et al. Reduced intensity conditioning is superior to nonmyeloablative conditioning for older chronic myelogenous leukemia patients undergoing hematopoietic cell transplant during the tyrosine kinase inhibitor era. Blood. 2012;119(17):4083-4090.

59. Miralbell R, Chapuis B, Nouet P, et al. Conditioning the leukemic patient before allogeneic BMT: value of intensifying immunosuppression in the context of different levels of T lymphocyte depletion of the graft. Bone Marrow Transplant. 1993;11(6):447-451.
60. Lan F, Zeng D, Higuchi M, Huie P, Higgins JP, Strober S. Predominance of NK1.1+TCR alpha beta+ or DX5+TCR alpha beta+ T cells in mice conditioned with fractionated lymphoid irradiation protects against graft-versus-host disease: "natural suppressor" cells. J Immunol. 2001; 167(4):2087-2096.

61. Seino K, Harada M, Taniguchi M. NKT cells are relatively resistant to apoptosis. Trends Immunol. 2004;25(5):219-221.

62. Lowsky R, Takahashi T, Liu YP, et al. Protective conditioning for acute graft-versus-host disease. N Engl J Med. 2005;353(13):1321-1331.

63. Storb R, Etzioni R, Anasetti C, et al. Cyclophosphamide combined with antithymocyte globulin in preparation for allogeneic marrow transplants in patients with aplastic anemia. Blood. 1994;84(3):941-949.

64. Tsirigotis P, Shapira MY, Or R, et al. The number of infused CD34+ cells does not influence the incidence of GVHD or the outcome of allogeneic PBSC transplantation, using reduced-intensity conditioning and antithymocyte globulin. Bone Marrow Transplant. 2010;45(7): 1189-1196.

65. Konopacki J, Porcher R, Robin M, et al. Long-term follow up after allogeneic stem cell transplantation in patients with severe aplastic anemia after cyclophosphamide plus antithymocyte globulin conditioning. Haematologica. 2012;97(5):710-716.

66. Bredeson CN, Zhang MJ, Agovi MA, et al. Outcomes following HSCT using fludarabine, busulfan, and thymoglobulin: a matched comparison to allogeneic transplants conditioned with busulfan and cyclophosphamide. Biol Blood Marrow Transplant. 2008;14(9):993-1003.

67. Rao A, Kamani N, Filipovich A, et al. Successful bone marrow transplantation for IPEX syndrome after reduced-intensity conditioning. Blood. 2007;109(1):383-385.

68. Bhatla D, Davies SM, Shenoy S, et al. Reduced-intensity conditioning is effective and safe for transplantation of patients with Shwachman-Diamond syndrome. Bone Marrow Transplant. 2008;42(3):159-165.

69. Morris E, Thomson K, Craddock C, et al. Outcomes after alemtuzumab-containing reduced-intensity allogeneic transplantation regimen for relapsed and refractory non-Hodgkin lymphoma. Blood. 2004;104(13):3865-3871.

70. Marsh JC, Gupta V, Lim Z, et al. Alemtuzumab with fludarabine and cyclophosphamide reduces chronic graft-versus-host disease after allogeneic stem cell transplantation for acquired aplastic anemia. Blood. 2011;118(8):2351-2357.

71. Marsh RA, Vaughn G, Kim MO, et al. Reduced-intensity conditioning significantly improves survival of patients with hemophagocytic lymphohistiocytosis undergoing allogeneic hematopoietic cell transplantation. Blood. 2010;116(26):5824-5831.

72. Khouri IF, Saliba RM, Hosing C, et al. Concurrent administration of high-dose rituximab before and after autologous stem-cell transplantation for relapsed aggressive B-cell non-Hodgkin's lymphomas. J Clin Oncol. 2005;23(10):2240-2247.

73. Escalon MP, Champlin RE, Saliba RM, et al. Nonmyeloablative allogeneic hematopoietic transplantation: a promising salvage therapy for patients with non-Hodgkin's lymphoma whose disease has failed a prior autologous transplantation. J Clin Oncol. 2004;22(12):2419-2423.

74. Weiner LM, Surana R, Wang S. Monoclonal antibodies: versatile platforms for cancer immunotherapy. Nat Rev Immunol. 2010;10(5): 317-327.

75. Sharkey RM, Goldenberg DM. Cancer radioimmunotherapy. Immunotherapy. 2011;3(3):349-370.

76. Gopal AK, Rajendran JG, Gooley TA, et al. High-dose [131I]tositumomab (anti-CD20) radioimmunotherapy and autologous hematopoietic stem-cell transplantation for adults $>$ or $=60$ years old with relapsed or refractory B-cell lymphoma. J Clin Oncol. 2007;25(11):1396-1402.

77. Bethge WA, Lange $\mathrm{T}$, Meisner $\mathrm{C}$, et al. Radioimmunotherapy with yttrium-90-ibritumomab tiuxetan as part of a reduced-intensity conditioning regimen for allogeneic hematopoietic cell transplantation in patients with advanced non-Hodgkin lymphoma: results of a phase 2 study. Blood. 2010;116(10):1795-1802. 
78. Abou-Nassar KE, Stevenson KE, Antin JH, et al. (90)Y-ibritumomab tiuxetan followed by reduced-intensity conditioning and allo-SCT in patients with advanced follicular lymphoma. Bone Marrow Transplant. 2011;46(12):1503-1509.

79. Pagel JM, Gooley TA, Rajendran J, et al. Allogeneic hematopoietic cell transplantation after conditioning with 131I-anti-CD45 antibody plus fludarabine and low-dose total body irradiation for elderly patients with advanced acute myeloid leukemia or high-risk myelodysplastic syndrome. Blood. 2009;114(27):5444-5453.
80. Cook G, Smith GM, Kirkland K, et al. Outcome following reduced-intensity allogeneic stem cell transplantation (reducedintensity conditioning AlloSCT) for relapsed and refractory mantle cell lymphoma (MCL): a study of the British Society for Blood and Marrow Transplantation. Biol Blood Marrow Transplant. 2010;16(10): 1419-1427.

\section{Publish your work in this journal}

Blood and Lymphatic Cancer: Targets and Therapy is an international, peer-reviewed, open access journal focusing on blood and lymphatic cancer research, identification of therapeutic targets and the optimal use of preventative and integrated treatment interventions to achieve improved outcomes, enhanced survival and quality of life for the cancer patient. The manuscript management system is completely online and includes a very quick and fair peer-review system. Visit http://www.dovepress.com/testimonials.php to read real quotes from published authors.

Submit your manuscript here: http://www.dovepress.com/blood-and-lymphatic-cancer-targets-and-therapy-journal 